\title{
Identification of Ixodidae ticks from cattle imported into the South Kivu province, east of the Democratic Republic of Congo
}

\author{
Muhimuzi A. Bisusa ${ }^{1}$, Marara E. Bizire ${ }^{2}$, Bujingo D. Muntuokuwindi', \\ Gilbert Nijimbere $^{4 *}$, Kashamuka R. Musimwa ${ }^{5}$, Vyambwera G.Ch. Kambale ${ }^{6}$ \\ ${ }^{1}$ Lwiro Natural Sciences Research Centre (NSERC_LWRO), Bukavu, Democratic Republic of Congo \\ ${ }^{2}$ Interdisciplinary Centre for Continuing Education (Cidep), Bukavu, Democratic Republic of Congo \\ ${ }^{3}$ Lwiro fiftieth anniversary University (UNI-50), Bukavu, Democratic Republic of Congo \\ ${ }^{4}$ Kuban State Agrarian University, Krasnodar, Russian Federation \\ ${ }^{5}$ National Institute for Agronomic Research (INERA), Mulungu, Democratic Republic of Congo \\ ${ }^{6}$ Catholic University of Graben (UCG), Butembo, Democratic Republic of Congo \\ *Corresponding author: gilbert.nijimbere@ub.edu.bi
}

\begin{abstract}
A survey has been conducted in Bukavu on bovines imported in Democratic Republic of Congo from Rwanda to the public slaughterhouse of Bukavu, with the aim of identifying the Ixodidae ticks on their body. Thus, 1024 ticks have been collected on 300 cows for the entomological identification. Four species have been identified whose Boophilus decoloratus (44.4\%), Rhipicephalus appendiculatus (43.9\%), Amblyomma variegatum (11\%) and Ixodes thomasai (2\%). This last species being a new among those recognized in South Kivu. A charge to ticks of 6.5 has been observed at those bovines and the infestation rate has been significantly different in the 4 races, the Friesland (41.1\%) and Ankolé presented the superior values. The importation of cows in this part of the country from Rwanda is a real factor which conducts to the introduction of ticks and also diseases in Democratic Republic of Congo. Then being measures of heath control in the border must be sustained and reinforced for minimizing real risks.
\end{abstract}

Keywords: Identification, Ticks, Ixodidae, Bovins, Imports, South Kivu, Democratic Republic of Congo

Article history:

Received: 11 June 2020. Accepted: 1 September 2020

For citation:

Bisusa MA, Bizire ME, Muntuokuwindi BD, Nijimbere G, Musimwa KR, Kambale VGCh. Identification of Ixodidae ticks from cattle imported into the South Kivu province, East of the Democratic Republic of Congo. RUDN Journal of Agronomy and Animal Industries. 2020; 15(3):294-307. doi: 10.22363/2312-797X-202015-3-294-317

(c) Bisusa M.A., Bizire M.E., Muntuokuwindi B.D., Nijimbere G., Musimwa K.R., Kambale V.G.Ch., 2020 


\section{Introduction}

Mismanagement and insufficient means of preventing animal diseases at the border is the basis for the introduction of several pathogens in many countries in Africa. The uncontrolled movement of cattle within and between countries constitutes a real source of spread of ticks and the diseases carried by them across the territories (Kabare, kalehe; Kaziba, Walungu, Mwenga...) and chiefdoms (Ninja, Luhwindja, Burhinyi,...) notably located at entry points and in environments of increased consumption of animal proteins in all provinces [1]. The work carried out by Bisusa and Rucacura on ticks in cattle in the Ruzizi plain noted the presence of Hyalomma truncantum [2]. The introduction into this breeding area was linked to the importation of cattle from Burundi and Tanzania. The presence of Rhipicephalus appendiculatus in Rwanda [3] and other species in South Kivu in the Democratic Republic of Congo [4-6], is an element which, in view of the livestock exchanges takes place between these two countries and indicate the possibility of transferring other ticks from one region to another. Ticks are obligate blood-sucking arthropods and represent one of the major constraints to the development of animal husbandry in Africa as elsewhere in the world $[5,7]$. They are sources not only of direct actions, such as skin irritations and blood spoliations, but also of indirect effects such as the transmission of pathogenic agents such as viruses, neuroviruses, bacteria and nematodes [8].

In addition, ticks and the diseases they transmit represent a major obstacle to the improvement and productivity of ruminant farming [9]. In an animal undergoing a significant infestation by ticks, weight loss and a decrease in milk production are observed; loss of appetite, anorexia and nasal discharge are also often observed [10].

Several species of ticks are at the basis of transmitting a variety of pathogens to mammals, particularly hard ticks such as Rhipicephalus appendiculatus, Boophilus decoloratus, Amblyomma variegatum, Hyalomma spp. [4, 11-14] are often found in cattle. These ticks therefore constitute a serious threat on farms if the appropriate measures are not taken [15]. The main diseases transmitted by ticks in tropical regions are Theileriosis, Babesiosis, Anaplasmosis and are responsible for more than $63 \%$ of animal mortality in several countries and the decline in productivity [16].

In eastern, central and southern Africa, annual losses due to the East Coast Fever, tick-borne illness (calculated in 1989) have been estimated at 168 million doll. including a mortality of more than 1.1 million cattle [17]. The situation remains worrying as a result of the movement of animals from one country to another without any form of provisions, to avoid their dissemination [18]. It is in this context that the present study was undertaken with a view to answering the question of whether the importation of cattle into Bukavu cannot also contribute to the importation of ticks, diseases and their spread in farms from South Kivu.

\section{Materials and methods}

Study environment / description of the Elakat slaughterhouse. The study was carried out at the main Elakat animal slaughterhouse located in the town of Bukavu, specifically in the commune of Ibanda, which is the place of arrival of cattle from neighboring 
countries. According to its history, this slaughterhouse dates back to colonial times, point of arrival and distribution of cattle and other animals in points scattered inside the province of South Kivu.

This Elakat site is located on the border, more to the east of the Democratic Republic of Congo not far from the Ruzizi river, which constitutes the border with the Republic of Rwanda. It is located in the commune of Ibanda which has a temperate mountain climate which has two seasons, one dry generally extending over four months and the other rainy extending over eight months. The average temperature varies between 22 and $27^{\circ} \mathrm{C}$. The land is rugged because it has many steep slopes that are unsuitable for house construction and agriculture. This is the case with Elakat (our study site), in the Ndendere district; Mbeke in the Panzi district and Ruzizi / Somenki in the Nyalukemba district. Its hydrography of Ibanda is as follows: Lake Kivu to the north, the Kawa river separating the commune of Ibanda from that of Kadutu; The Mukukwe river which rises in the Ndendere district and flows into the Ruzizi river, always passing through the same district; the Ruzizi river which is an outlet from Lake Kivu and on which the Ruzizi hydroelectric dam was erected.

In this region animals, particularly cattle come from neighboring countries via Rwanda to Bukavu at the level of the slaughterhouse where part is slaughtered and another recovered by breeders depending on the breed and the performance of the cattle for their breeding. Slaughterhouse operates every day and receives animals coming from abroad on Tuesday and Thursday at the border, no zoo-sanitary provisions apply even though they are provided for by law (quarantine, sprinkling, deworming, etc.) more concerned with Elakat are cattle, although at times we also find a few pig heads there, but in small numbers.

Harvest, conservation and identification. The rate of passage to harvest was weekly. In well-contained animals, ticks were searched all over the body, starting with preferential fixation sites such as the ear, base of the horns, ventral or abdominal region, anal and genital regions and baleen. The technique involved inspecting and searching the coat. Thus, all the ticks encountered were removed using anatomical forceps or by hand between the thumb and forefinger by simple manipulation. This traction should be gentle and done gently so as not to damage the rostrum which is important in the diagnosis of ticks [19]. The harvested ticks were then kept in labeled vials containing $70 \%$ ethanol, thus sparing them from alteration which could make identification impossible to avoid rapid dehydration of the samples and further soften their seed coat, on each label was marked: the identification number of the animal, the date of harvest, and the breed of the animals. Thus, the preserved samples were sent to the Veterinary Entomology laboratory of the Lwiro Natural Sciences Research Center (CRSN / Lwiro) for their identification. The contents of each vial were sorted to separate the larvae from nymphs and adults. Subsequently, a count of each stage of development was carried out and followed by an identification based on the morpho-anatomical characteristics while knowing that the study focused on certain morphological details such as, in addition to the characters to identify the gender, shape of teeth, color and shape of eyes, shape of genital and anal openings, punctuation of scutum, lateral furrows and media, color and shape of legs with or without hair, shape of scallops as described by some authors [20—23]. 
Statistical analyzes. The data obtained from the collection of ticks and their identification were, for their interpretation, subjected to the Pearson Chi-Square test, according to the model proposed by Leroy and Farnir [24], at a risk p of 5\%, for one degree of freedom (dof) equal to 9. The frequency of ticks was determined from the simple calculation of the percentage according to the following mathematical expression:

With $x$ the frequency observed on a sample and $n$ number of ticks.

\section{Results}

In this study, 1063 ticks collected from 300 cattle from Rwanda were subjected to morphological identification. The identification resulted in four different species belonging to four different genera. These species have been successively represented by: Rhipicephalus appendiculatus, Boophilus decoloratus, Amblyomma variegatum and Ixodes thomasai.

The tick load was determined in the four breeds of cattle involved and the influence of the breed on the frequency of these ticks was also studied. In Table 1 below are presented the results relating to the tick load by breed of cattle.

Table 1

Tick load in cattle breeds at Elakat slaughterhouse

\begin{tabular}{|c|c|c|c|c|c|}
\hline $\mathrm{N}^{\circ}$ & $\begin{array}{c}\text { Race/ } \\
\text { Bovine }\end{array}$ & $\begin{array}{c}\text { Bovines number } \\
\text { examined }\end{array}$ & $\begin{array}{c}\text { Bovines number examined } \\
\text { infestés }\end{array}$ & Ticks number & $\begin{array}{c}\text { Bovine Charge } \\
\text { ticks by races }\end{array}$ \\
\hline 1 & Ankolé & 100 & 65 & 396 & 6 \\
\hline 2 & Frisian & 96 & 61 & 440 & 7.2 \\
\hline 3 & Swiss brown & 63 & 29 & 176 & 6 \\
\hline 4 & Jersey & 41 & 08 & 51 & 6.3 \\
\hline Total & & 300 & 163 & 1063 & 6.5 \\
\hline
\end{tabular}

In table 1, it appears that for 300 cattle examined 4 breeds of cattle were concerned in particular: Ankolé, Frisian, Swiss brown and jersey. For the Ankolé, we found 396 ticks on 65 cattle, a load of 6 ticks per cattle. For the Frisians we found 440 ticks on 61 cattle, a load of 7.2 ticks per cattle. While for Swiss Browns, 176 ticks out of 29 cattle and the load was 6 ticks per cattle and on Jersey at the end 51 ticks were collected from 8 cattle and a load of 6.3 ticks per cattle.

Of the 300 cattle examined, 163 cattle or $54.3 \%$ were infested with ticks and the total burden of ticks per cattle was 6.5 ticks.

From table 2: it notes that for the four cattle breeds, four species of ticks were identified. From these breeds of cattle, the Ankole alone had a total of 396 ticks or $35.2 \%$ of ticks including: 60 male ticks, 73 female ticks and 23 nymphs (Rhipicephalus appendiculatus), 8 males, 167 females and 15 nymphs (Boophilus decoloratus), 32 males, 10 females (Amblyomma variegatum), and 8 females (Ixodes thomasai). For the Friesians we identified a total of 500 ticks or $44.4 \%$ including 95 males, 90 females and 43 nymphs (Rhipicephalus appendiculatus), 9 males, 114 Females and 67 nymphs (Boophilus decoloratus), 67 males, 34 females, and 11nymphs (Amblyomma variegatum) and only 7 females (Ixodes thomasai). 
Frequency of tick species found in cattle breeds at the Elakat slaughterhouse

\begin{tabular}{|c|c|c|c|c|c|c|c|c|c|c|c|c|c|c|c|}
\hline \multirow{3}{*}{$\mathbf{N}^{\circ}$} & \multirow[t]{3}{*}{ Breed } & \multicolumn{13}{|c|}{ Species of ticks } & \multirow{3}{*}{ Total (\%) } \\
\hline & & \multicolumn{3}{|c|}{ Rhip. app } & \multicolumn{3}{|c|}{ Boo.dec } & \multicolumn{3}{|c|}{ Ambly.var } & \multicolumn{3}{|c|}{ Ixod.thom } & \multirow{2}{*}{$\frac{-}{\mathrm{nb}}$} & \\
\hline & & $M$ & $\mathrm{~F}$ & $\mathbf{N}$ & M & $F$ & $\mathbf{N}$ & $M$ & $\mathrm{~F}$ & $\mathbf{N}$ & $M$ & $\mathrm{~F}$ & $\mathbf{N}$ & & \\
\hline 1 & Ankolé & 60 & 73 & 23 & 8 & 167 & 15 & 32 & 10 & 0 & 0 & 8 & 0 & & \multirow{2}{*}{35.2} \\
\hline & TOTAL & \multicolumn{3}{|c|}{156} & \multicolumn{3}{|c|}{190} & \multicolumn{3}{|c|}{42} & \multicolumn{3}{|c|}{8} & 396 & \\
\hline & $\begin{array}{c}2 \\
\text { Frisian }\end{array}$ & 95 & 90 & 43 & 9 & 144 & 67 & 34 & 11 & 0 & 0 & 7 & 0 & & \multirow{2}{*}{44.4} \\
\hline & TOTAL & \multicolumn{3}{|c|}{228} & \multicolumn{3}{|c|}{220} & \multicolumn{3}{|c|}{45} & \multicolumn{3}{|c|}{7} & 500 & \\
\hline 3 & Swiss brown & 26 & 34 & 15 & 2 & 66 & 6 & 11 & 10 & 0 & 0 & 6 & 0 & & \multirow{2}{*}{15.6} \\
\hline \multicolumn{2}{|r|}{ Total } & \multicolumn{3}{|c|}{75} & \multicolumn{3}{|c|}{74} & \multicolumn{3}{|c|}{21} & \multicolumn{3}{|c|}{6} & 176 & \\
\hline 4 & Jersey & 15 & 11 & 9 & 1 & 11 & 0 & 3 & 2 & 0 & 0 & 0 & 0 & & 4.6 \\
\hline & TOTAL & & 35 & & & 12 & & & 5 & & & 0 & & 52 & \\
\hline & Total (\%) & & $4(43$ & & & $6(44$ & & & $3(1$ & & & $(2$. & & $1124(100)$ & 100 \\
\hline
\end{tabular}

Legend: M: male; F: femelle; N: nymphe; nb: number.

Rhip. app: $\rightarrow$ Rhipicephalus appendiculatus; Boo.dec: Boophilus decoloratus Ambly.var: Amblyomma variegatum; Ixod.thom: xodes thomasai.

For Swiss brown 182 ticks were found including 26 males, 34 females and 15 nymphs (Rhipicephalus appendiculatus), 2 males, 66 females and 6 nymphs (Boophilus decoloratus), 11 males 10 females (Amblyomma variegatum), and finally 6 females (Ixodes thomasai). As for the Jersey breed we have identified a total of 52 ticks including 15 males, 10 females and 9 nymphs for Rhipicephalus appendiculatus, 1 male and 11 females for Boophilus decoloratus, 3 males and 2 females for Amblyomma variegatum. The different evolutionary stages of ticks have been encountered except for the nymphs for A. variegatum and Ixodes thomasai; eggs and larvae for the four species have not been identified due to lack of suitable equipment.

For the four species identified, Boophilus decoloratus (44.4\%) and (Rhipicephalus appendiculatus (43.9\%) presented relatively higher frequencies than Amblyomma variegatum (11\%) and Ixodes thomasai (2\%). For the breed of cattle, 396 ticks or $35.2 \%$ were collected on Ankolé cattle, 500 or $44.4 \%$ on Friesian cattle, 182 or $15.6 \%$ on Swiss brown and 52 or $4.6 \%$ on the Jersey breed. Statistical analysis of this result showed that the frequency of ticks on cattle from Rwanda in the Bukavu slaughterhouse varied significantly according to the breed. The Friesian (41.4\%) and Ankolé (37.2\%) breeds were more infested than the Alpine brown and Jersey.

\section{Discussion}

The tick load by breed of bovine was studied during our investigations. This load appeared arithmetically the same in the four breeds of cattle although a value of 7.2 ticks per cattle was observed in the Friesian breed. The overall tick load per cattle was 6.5. The 
latter remains below the values of 82 ticks and 72 ticks reported respectively for cattle from the Democratic Republic of Congo [17]. The load of 6.5 ticks for cattle importing into the Democratic Republic of Congo, via Rwanda for Bukavu in South Kivu remains lower than that of 7 ticks for cattle from Belgium [25, 26].

Regarding the rates of infestation and species of ticks, we were able to observe four species of ticks, namely Rhipicephalus appendiculatus, Boophilus decoloratus, Amblyomma variegatum and Ixodes thomasai. These results are similar to those obtained by Vyambwera [4] in South Kivu where, in addition to the first three species, he identified the species Rhipicephalus evertsi evertsi and Hyalomma marginatum rufipes. The presence of Ixodes thomasai on cattle imported from Rwanda would constitute an additional danger since its presence would be recent in South Kivu and there is reason to fear its spread within the various herds from the slaughterhouse in Bukavu. Statistical analysis showed that the Ankolé (35.2\%) and Frisian (44.4\%) breeds were more parasitized. The high infestation rate of Ankole cattle and that of the Swiss brown and Jersey breeds is different from the results reported by Vyambwera and his collaborators [9]. For cattle from Beni Lubero, in North Kivu where exotic breeds were more parasitized than natives and where also the ticks Rhipicephalus appendiculatus, Boophilus decoloratus and Amblyomma variegatum were identified. The reduced infestation rate observed in Swiss brown (15.6\%) and Jersey (4.6\%) cattle may be related to the fact that these animals have developed a certain resistance to ticks, perhaps as a result of more than treatment followed by acaricide products previously that continuing to circulate the metabolism of these cattle. The most prevalent ticks are Boophilus decoloratus followed by Rhipicephalus appendiculatus, which are also those which transmit bovine theileriosis, a very deadly disease of cattle. East coast fever remains probably the most important livestock disease in Africa [26].

The economic importance of this disease is first of all due to the number of animals at risk. In 1982, 250 million cattle were at risk of tropical heather in the world [27]. In addition, tropical heather causes financial losses inherent in mortality recorded in adults as well as young people, in abortions, as well as in the cost of medical treatment, the latter being one of the most costly in bovine pathology [28], the economic losses are caused by the decreases in production (of milk and meat) which are all the more important as they affect both infected animals showing clinical signs and those presenting sub-clinical or even asymptomatic infections [29].

For these four imported cattle breeds namely: Ankolé, Frisian, Swiss brun and jersey, each of them had their own objective of being paid by the buyers at the Elakat slaughterhouse. Mainly for the Ankolé i.e. local cows with long horns, this breed was bought by butchers to convert them into meat at sales outlets, slaughterhouses (Bukavu), markets (Kadutu, Mudaka, Kavumu, Katana; Kabamba), group purchasing of cattle in companies (INERA, Pharmakina, CRSN-Lwiro, and butchers in towns and cities. This breed of cattle has few of weight and a simple corpulence is also doomed to perform long distances. They are found towards Shabunda, Kamituga, Kasaï in the interior of the Democratic Republic of Congo. However, for these three other breeds of cattle including: Frisian, Swiss brown and Jersey being of large build and high intensity of milk production and meat, they are preferred and bought more by local breeders under penalty of also having to produce for them. For this reason, their prices remain high, costing three or even four times the Ankolé cow. 
Acaricides aim to reduce the tick population by cutting their life cycle, by eliminating adult ticks in the dry season and immature ticks (larvae and nymphs) in the rainy season [29]. By eliminating ticks, miticides help fight all the diseases they transmit. The classic method uses acaricides in baths or sprays. The use of impregnated acaricides (ear loops) although not yet used in our region, their slow release has the disadvantages of being expensive; it may be the cause of residual contamination of meat and milk [30]. Continued use of acaricides increases the risk of tick resistance, and the breakdown of anti-tick immunity leads to a loss of balance in endemic stability, rounding animals more susceptible to infection [31] acaricides should be used for both exporting and importing countries.

\section{Conclusion}

Although the tick load of 6.5 is lower for imported cattle and indicates a certain level of compliance with external deworming measures during the journey, it is still important to note the danger that these cattle would represent for livestock from South Kivu in view of the tick load for the farms from which these animals come. For the purposes of this study, we were unable to access data on the tick load for cattle from Rwanda between 2006 and today. It is also possible that these cattle have picked up ticks during the few minutes or hours of stay at the slaughterhouse in the Democratic Republic of Congo. It would therefore be ideal to collect from the cattle in the vehicle, at the point of entry into the Democratic Republic of Congo. However, a fight against ticks at the border would be an asset. The fight against ticks includes chemical control (spraying cattle during their crossing), agronomic control (rotation of pasture, brushing, grazing its animals on a well-defined space before their sale for the interior of the country), control genetics (use of less sensitive breeds), biological control (introduce cattle ranching). The development of new plant-based acaricides, local products (Vernonia amygdalina, Tephrosia vogelii,...) remains to be hoped because the chemical molecules are at the origin of environmental pollution and the risk of the presence of residues in the Human food is not negligible, and it also affects non-target species, which are present in the environment and present a high cost. The success of the fight against tropical theileriosis depends to a large extent on a good knowledge of the epidemiology of this protozoal disease in order to adapt the control strategy to the target area. Overall, this strategy is based on miticides control measures against the vector tick and on the vaccination of cattle against T. parva. The fight against ticks and the diseases they transmit to cattle such as theileriosis, babesiosis, anaplasmosis, Lyme disease, in DR Congo as in neighboring countries must be carried out according to a global strategy: (i) integrating the various control measures and detailed monitoring in quarantine service, following an economic cost-benefit approach, (ii) aiming in the medium term to achieve the eradication of the disease, given the significant losses caused by the asymptomatic carrier state, (iii) taking into account the particularities of each endemic state; (iv) integrating an extension component taking into account the erroneous perception of the transmission of diseases to buyer-breeders.

\section{References}

1. Rodhain F, Perez C. Les tiques Ixodidae: systématique, biologie, importance médicale. In: Précis d'entomologie médicale et vétérinaire. Paris: Maloine; 1985. p.341-350. (In french)

2. Bisusa MA, Kujirabwinja RE. Présence de Hyalomma trucantum, une nouvelle tique de la plaine de la Ruzizi, Est de la République démocratique du Congo, par l’importation des races améliorées des bovins de la Tanzanie et du Burundi. International Journal of Innovation and Scientific Research. 2016; 26(1): 331-340. (In french) 
3. Bazarusanga T, Vercruysse J, Marcotty T, Geysen D. Epidemiological studies on Theileriosis and the dynamics of Theileria parva infections in Rwanda. Veterinary Parasitology. 2007; 143(3-4):214-221. doi: 10.1016/j.vetpar.2006.09.009

4. Vyambwera G.C.K et al. Parasitisme dû aux tiques en zone d’élevage bovin de Béni-Lubero. Par cours et Initiative, CRIG, Production et santé Animale, 2009; 6, 22-31. (In french)

5. Bisusa M, Amzati S, Bagalwa M. Distribution altitudinale actuelle des tiques (Acarina-Ixodidae) chez les bovins élevés dans les groupements de Bugorhe et Irhambi-Katana en territoire de Kabare, Sud-Kivu, RDC. Annales de l'UEA, Numéro spécial sur l'environnement. 2014; p.69-80.

6. Amzati S. Modélisation par enquête rétrospective de l'épidémiologie de la Théilèriose bovine au SudKivu, dans l'Est de la République Démocratique du Congo. [Dissertation]; 2011. (In french)

7. Ogden N, Mechai S, Margos G. Changing geographic ranges of ticks and tick-borne pathogens: drivers, mechanisms and consequences for pathogen diversity. Front Cell Infect Microbiol. 2013; 3:46. doi: 10.3389/ fcimb.2013.00046

8. Farougou S. Les tiques et les maladies transmises au bétail en Afrique tropicale: les hémoparasitoses et la Cowdriose. [Dissertation] Bénin; 2007. (In french)

9. Kalume MK, Saegerman C, Mbahikyavolo DK, Makumyaviri AM, Marcotty T, Madder M, et al. Identification of hard ticks (Acari: Ixodidae) and seroprevalence to Theileria parva in cattle raised in North Kivu Province, Democratic Republic of Congo. Parasitol Research. 2013; 112(2):789-797. doi: 10.1007/s00436-012-3200-7

10. Morel PC. Maladies à tiques du bétail en Afrique. In: Chartier C, Itard J, Morel PC, Troncy PM. (eds.) Précis de Parasitologie Vétérinaire Tropicale. Paris: Internationales, TEC \& DOC; 2000. p.452-761. (In french)

11. FAO. Report of the FAO expert consultation on revision of strategies for the control of ticks and tickborne diseases, Rome, 25-29 September 1989. Parassitologia. 1990; 32:3-12.

12. Service MW. (ed.) Encyclopedia of arthropod-transmitted infections of man and domesticated animals. Liverpool: CABI Publishing; 2001.

13. Uilenberg G. Immunization against diseases caused by Theileria parva: a review. Trop Med Int Hlth. 1999; 4(9): A12-A20. doi: 10.1046/j.1365-3156.1999.00446.X

14. Kalume MK. Abondance saisonnière des tiques (Acari: Ixodidae) en fonction de système d'élevage des bovins dans la ville de Butembo, Province du Nord-Kivu, République Démocratique du Congo, Ed. Parcours et initiatives. 2012; 9:56-66. (In french)

15. Madder M, Thys E, Achi L, Toure A, De Deken R. Rhipicephalus (Boophilus) microplus: amost successful invasive tick species in West-Africa. Exp Appl Acarol. 2011; 53(2):139-145. doi: 10.1007/s10493-010-9390-8

16. D’haese L, Penne K, Elyn R. Economics of theileriosis control in Zambia. Trop Med Int Heath. 1999; 4(9): A49-A57. doi: 10.1046/j.1365-3156.1999.00451.x

17. Bisusa M, Kalume KM, Masunga MB. Abondance saisonnière des tiques (Acarina-Ixodidae) parasites des bovins élevés dans les territoires de Kabare, Sud-Kivu, RD Congo, parcours et initiation n¹1, 2013: 226-235 (In french)

18. Balagizi KI, Ngendakumana S, Mushayuma NH, Adhama MT, Bisusa MA, Baluku B, et al. Perspectives de gouvernance environnementale durable dans la région de Lwiro (Sud Kivu, République Démocratique du Congo). Vertig O. 2013; 17. (In french) doi: 10.4000/vertigo.13826

19. Faraji F, Bakker F. A modified method for clearing, staining and mounting plant-inhabiting mites. European Journal of Entomology. 2008. 105(4):793-795.

20. Larmontellerie M. Tiques (Acarina- Ixodidae) de la Haute-Volta. Bulletin de l'Institut Fondamental d'Afrique Noire, Series A: Sciences Naturelles. 1966; 28:597-642. (In french)

21. Morel PC. Contribution à la connaissance à la distribution des tiques (Acariens, Ixodidae et Amblyommidae) en Afrique Ethiopienne continentale [Dissetation] Paris; 1969. (In french)

22. Charier C, Itard J, Morel PC, Troncy PM. Précis de parasitologie vétérinaire tropicale. Paris: Technique et documentation; 2000. (In french)

23. Walker AR, Bouattour A, Camicas JL, Estrada-Peña A, Horak IG, Latif AA, et al. Ticks of Domestic Animals in Africa: a Guide to Identification of Species. Scotland: Bioscience Reports; 2003.

24. Leroy P, Farnir F. Méthodes statistiques en Médecine vétérinaire. Liège: Faculté de Médecine Vétérinaire; 2001. (In french)

25. Bisusa MA, Wabo BA, Bora NJ, Mampasi BM, Eugide BR, Christophe NB, et al. Performance reproductive des tiques évaluées dans les conditions du laboratoire, au centre de recherche en sciences naturelles de Lwiro, Sud-Kivu, République Démocratique du Congo. International journal of innovation and scientific research. 2018; 38:1-6. (In french)

26. Adehan SB, Biguezoton A, Adakal H, Dossa F, Dougnon TJ, Youssao E, et al. Acaricidal activity of ethanolic and volatile extracts of the leaves of selected plants used in veterinary pharmacopeia on the larvae of Rhipicephalus microplus in Benin. Alexandria Journal of Veterinary Sciences. 2016; 49(1):1-11. doi: 10.5455/ajvs.216241

27. Olwoch JM, Reyers B, Engelbrecht FA, Erasmus BFN. Climate change and the tick-borne disease, Theileriosis (East Coast fever) in sub-Saharan Africa. Journal of Arid Environments. 2008; 72(2):108-120. doi: 10.1016/j.jaridenv.2007.04.003 
28. Gachohi JM, Kitala PM, Ngumi PN, Skilton RA. Environment and farm factors associated with exposure to Theileria parva infection in cattle under traditional mixed farming system in Mbeere District, Kenya. Tropical Animal Health and Production. 2011; 43(1):271-277. doi: 10.1007/s11250-010-9688-x

29. Gharbi M, Sassi L, Dorchies P, Darghouth MA. Theileria annulata in Tunisia: economic analysis and evaluation of the potential benefit of vaccination. Vet Parasitol. 2006; 137(3-4):231-241. doi: 10.1016/j. vetpar.2006.01.015

30. Darghouth MA, Bouattour A, Kilani M. Theileriosis. In: Lefevre PC, Blancou J, Chermette R. (eds.) Principales maladies infectieuses du bétail, Europe et régions chaudes II. Paris: TEC \& DOC; 2003. (In french)

31. Boulter N, Hall R. Immunity and vaccine development in the bovine theileriosis. Advances in Parasitolology. 1999; 44:41-97.

\begin{abstract}
About authors:
Bisusa Muhimuzi Alphonse - Researcher in Environmental Sciences, Head of Veterinary Entomology Laboratory, Research Associate, Department of Biology, Research Center in Natural Sciences, CRSN-Lwiro, D.S. Bukavu, Sud-Kivu, Democratic Republic of Congo; e-mail: bisusamuhimuzi@gmail.com

Bizire Marara Emmanuel — Assistant, Interdisciplinary Center for Continuing Education (CIDEP) of Bukavu, Bukavu, South Kivu, 1550, Democratic Republic of the Congo; e-mail: ebmara@gmail.com

Muntuokuwindi Bujingo Donatien — Caring Agent of animals in community in Kabare territory, South Kivu, consultant at Veterinary Without Border Belgium (VSF); D.S. Bukavu, Democratic Republic of the Congo; e-mail: mb.donatien@gmail.com

Nijimbere Gilbert - PhD student, Department of Genetics and Plant Breeding, Faculty of Agriculture and Ecology, Kuban State Agrarian University, 13 Kalinina st., Krasnodar, 350044, Russian Federation; e-mail: gilbert.nijimbere@ub.edu.bi

Musimwa Kashamuka Roger - Assistant, National Institute for Agronomic Study and Research (INERA-Mulungu) at the legumes programme, D. S Bukavu, Democratic Republic of the Congo; e-mail: musimwakashamuka@ gmail.com

Kambale Vyambwera Guido-Charles - MSc in Animal Health, Faculty of Veterinary Medicine, Catholic University of Graben, B. P. 29 Butembo, North Kivu, Democratic Republic of the Congo; e-mail: gkambale@gmail.com

\section{Идентификация иксодовых клещей крупного рогатого скота, завезенного в провинцию Южное Киву Демократической Республики Конго}

\author{
М.А. Бисуза ${ }^{1}$, М.Э. Бизире ${ }^{2}$, Б.Д. Мунтуокувинди ${ }^{3}$, \\ Ж. Нижимбере ${ }^{4 *}$, К.Р. Мусимва ${ }^{5}$, В.Г.Ш. Камбале ${ }^{6}$
}

${ }^{1}$ Научно-исследовательский центр естественных наук Лвиро, г. Букаву, Демократическая Республика Конго

${ }^{2}$ Междисциплинарный центр непрерывного образования,

2. Букаву, Демократическая Республика Конго

зуниверситет пятидесятой годовщины Лвиро, г. Букаву, Демократическая Республика Конго ${ }^{4}$ Кубанский государственный аграрный университет, г. Краснодар, Российская Федерация

${ }^{5}$ Национальный институт аграрных исследований,

2. Мулунгу, Демократическая Республика Конго

${ }^{6}$ Католический университет Грабена, г. Бутембо, Демократическая Республика Конго *gilbert.nijimbere@ub.edu.bi

Аннотация. Проведена оценка состояния животных на предмет наличия иксодовых клещей у крупного рогатого скота, завезенного на общественную скотобойню в г. Букаву Демократической Республики Конго из Руанды. В результате исследования на 300 коровах и быках для энтомологической идентификации 
было собрано 1024 клеща. Идентифицированы четыре вида: Boophilus decoloratus (44,4\%), Rhipicephalus appendiculatus (43,9\%), Amblyomma variegatum (11\%) и Ixodes thomasai (2\%). Последний вид является новым для территории Южного Киву. Коэффициент заражения клещами у этих животных составил 6,5, а степень поражения различалась в зависимости от породы, наиболее высокие значения отмечались у Фризской $(41,1 \%)$ и Анколе. Ввоз крупного рогатого скота в эту часть страны из Руанды является важным фактором, который ведет к появлению и распространению клещей, а также вызываемых ими болезней в Демократической Республике Конго. Таким образом, меры по контролю ввоза крупного рогатого скота на границе должны быть устойчивыми и усиленными для минимизации потенциальных рисков.

Ключевые слова: идентификация, зараженность, клещи, иксодовые клещи, Ixodidae, коровы, быки, Южный Киву, Демократическая Республика Конго

\section{История статьи:}

Поступила в редакцию: 11 июня 2020 г. Принята к публикации: 1 сентября 2020 г.

\section{Для цитирования:}

Bisusa M.A., Bizire M.E., Muntuokuwindi B.D., Nijimbere G., Musimwa K.R., Kambale V.G.Ch. Identification of Ixodidae ticks from cattle imported into the South Kivu province, East of the Democratic Republic of Congo // Вестник Российского университета дружбы народов. Серия: Агрономия и животноводство. 2020. Т. 15. № 3. С. 294-317 doi: 10.22363/2312-797X-2020-15-3-294-317

\section{Об авторах:}

Бисуса Мухимузи Альфонс — научный сотрудник, руководитель лаборатории ветеринарной энтомологии, кафедра биологии, Центр естественных наук, Лвиро, Демократическая Республика Конго, г. Букаву; e-mail: bisusamuhimuzi@gmail.com

Бизире Марара Эммануэль — ассистент, Междисциплинарный центр непрерывного образования (CIDEP), Демократическая Республика Конго, Южная Киву, г. Букаву; e-mail: ebmara@gmail.com

Мунтуокуийнди Донасьен Буджинго - агент по уходу за животными в общине на территории кабаре, консультант, ветеринарная служба без границ Бельгии (VSF); Демократическая Республика Конго, Южная Киву, г. Букаву; e-mail: mb.donatien@gmail.com

Нижимбере Жилбер - аспирант кафедры генетики и селекции растений, факультет агрономии и экологии, Кубанский государственный аграрный университет, 350044, Российская Федерация, г. Краснодар, ул. Калинина, д. 13; e-mail: gilbert.nijimbere@ub.edu.bi

Мусимва Кашамука Роджер - ассистент, Национальный институт агрономических исследований и исследований (инера-Мулунгу) по программе бобовых культур, Демократическая Республика Конго, Южная Киву, г. Букаву; e-mail: musimwakashamuka@gmail.com

Камбале Вьямбвера Гвидо-Шарль — магистр, факультет ветеринарной медицины, Католический университет Грабена, Демократическая Республика Конго, Северная Киву, г. Бутембо Б.П. 29; e-mail: gkambale@ gmail.com 